\title{
Early development of Hypogymnia physodes (L.) Nyl. in response to emissions from a copper smelter
}

\author{
Irina N. MIKHAILOVA and Christoph SCHEIDEGGER
}

\begin{abstract}
The early development of Hypogymnia physodes from soredia to the formation of stratified lobes has been studied experimentally in the vicinity of a copper-smelting plant in the Middle Urals. SEM investigations combined with life table analyses of early developmental stages revealed decreases in soredial survival and developmental rate in polluted localities. Non-stifified pre-thallus stages without an epicortex were tolerant to toxic impact and were able to survive even in the zone with the highest pollution (lichen desert zone). The sensitivity of developmental stagesincreased after stratified lobes had developed.

c. 2001 The British Lichen Society
\end{abstract}

\section{Introduction}

Lichens are well known and widely used as biomonitors of various gaseous and particulate air pollutants. A decrease in the number of species and their frequency are the most obvious results of a toxic impact on lichen communities (Skye 1968; Nash \& Gries 1991; Richardson 1992; Gries 1996). In polluted areas, morphological changes in both naturally occurring and transplanted thalli have been found, including changes in thallus colour, total bleaching and crevice formation in thalli (see Nash \& Gries 1991; Gries 1996). A decline in apothecia formation has been shown in a number of species (De Sloover \& LeBlanc 1970; Sigal \& Nash 1983). However, production of soredia and isidia under the influence of $\mathrm{SO}_{2}$ (see DeSloover \& LeBlanc 1970) and pycnidial formation under oxidant pollution (Sigal \& Nash 1983), are stimulated. Anatomical alterations include changes in thickness of

I. N. Mikhailova: Institute of Plant and Animal Ecology UD RAS, 8 Marta Str., 202, 620144 Ekaterinburg, Russia.

C. Scheidegger: WSL Swiss Federal Research Institute, CH-8903 Birmensdorf, Switzerland. thallus layers, for example, a decrease in cortex thickness and an increased thickness of the photobiont layer in Hypogymnia physodes from urban sites (Holopainen 1984). Physiological and ultrastructural changes have also been reported in a number of species (see Gries 1996; Garty 2000).

Little is known, however, about the effects of pollutants on the age structure and persistence of lichen populations. Recently detailed studies in the Middle Urals (Mikhailova \& Vorobeichik 1999) revealed a sharp shift in $H$. physodes population structure towards smaller, non-sorediate and sparingly sorediate thalli under the polluted conditions. Moreover, individual thalli from polluted populations released a lower number of soredia compared to thalli of the same developmental stage growing in a nonpolluted area (Mikhailova 1998). Overall, the above-mentioned phenomena lead to a sharp reduction in the total production of diaspores by populations growing in polluted localities. It is, however, still not known whether an increased death rate, or a decreased germination and developmental rate or a combination of the two, lower the population density and cause a shift in population age structure. Since diaspores in 
the polluted areas are faced with lower interspecific competition, a higher success of the early stages of thallus development could compensate for a reduced number of diaspores released. Schuster (1985) reported a high tolerance of first developmental stages to the pollution from a motorway (up to five months) whereas subsequent stages were affected. However, laboratory experiments (Marti 1985) showed a reduced germination rate of $H$. physodes soredia when placed on agar plates containing an $\mathrm{SO}_{2}$ fumigated bark extract.

The aim of this study was to investigate possible pollution-related differences in the early development of soredia and to investigate qualitatively transitions among different developmental stages in the life cycle of H. physodes.

\section{Methods}

The study was carried out in the vicinity of a copper smelter located near Revda $(50 \mathrm{~km}$ west of Ekaterinburg) in the Middle Urals. The climate is moderately continental, with an annual average rainfall of $400-600 \mathrm{~mm}$. The depth of snow cover is $40-50 \mathrm{~cm}$ or more. The mean annual temperature is $+1^{\circ} \mathrm{C}$; mean January and July temperatures are -16 to $-17^{\circ} \mathrm{C}$ and +16 to $18^{\circ} \mathrm{C}$, respectively. The duration of the frostfree period is 90 days and the prevailing winds are westerly and south-westerly (Prokaev, 1976).

The area belongs to the southern taiga phytogeographical subzone with a forest cover of about $60 \%$ consisting of mostly secondary forests with mixed coniferous and deciduous trees as well as birch and aspen stands (Kolesnikov et al., 1973).

The copper smelter has been functioning since 1940 emitting particulate and gaseous pollutants in the ratio $1: 8 \cdot 44$. Sulphur dioxide constitutes $98.7 \%$ of the gaseous pollutants, and copper, zinc, arsenic, and lead constitute $46 \cdot 9,31 \cdot 5,11 \cdot 5$, and $10 \cdot 1 \%$ of the particulate pollutants, respectively (Vorobeichik et al. 1994). Distinct zones of forest damage are evident around the emission source (Vorobeichik et al. 1994; Vorobeichik \& Khantemirova 1994; Scheidegger 1998; Scheidegger \& Mikhailova 2000). Sample sites were established in four zones determined in previous investigations according to the degree of lichen community transformation (Mikhailova 1994): lichen desert, impact, buffer and background. In each pollution zone, three localities were chosen where the proportion of birch (Betula pubescens or $B$. pendula) in a tree stand is $>20 \%$. The characteristics of the sample sites are summarized in Table 1.

The experiment commenced during May 1995. Airdry healthy thalli of $H$. physodes were collected from birch trunks in the background zone and placed in plastic bags. Bark squares (c. $1 \mathrm{~cm}^{2}$ ) were cut from the basal parts of birch trees in the background area. Bark samples were carefully cleaned of lichens with a rough brush, checked under a dissecting microscope and glued on 15-20 cm long wooden bars (10 samples per bar). Immediately before the sowing, the surface of the bark squares was wetted with a paintbrush. Soredia were collected from walls of the plastic bags using a wet paintbrush and transferred onto the bark samples. To ensure occupancy of all potential microsites, the surface of the bark squares was covered by the dense layer of soredia. No strict quantitative control of numbers of soredia transferred was made at this stage. Three birch trees per locality were chosen and two bars attached vertically to each trunk, with a plastic ribbon, one at the base and one at $130 \mathrm{~cm}$ above ground. A total of 720 bark squares (four zones $\times$ three localities $\times$ three trees $x$ two positions on the trunk $\times 10$ ) were used.

During the first year, soredial development was assessed after 2 (July 1995) and 4 (September 1995) months of exposure, and in subsequent years at the beginning and at the end of each growing season, i.e. after 12 (May 1996), 16 (October 1996), 25 (June 1997) and 29 (October 1997) months of exposure. The numbers of diaspores, regardless of their developmental stage, were counted on each bark square on all bars under a dissecting microscope in the laboratory. After each assessment, the bars were replaced in the field. After 25 months, the growth of surrounding thalli interfered with the specimens so that quantitative analysis of soredial development was no longer possible.

Survival of diaspores was calculated as a percentage of the number of soredia present after 2 months of exposure. Soredia surviving two months of exposure was taken as a baseline, on the assumption that soredia placed in unsuitable microsites would have been lost in the water run-off by this time while survivors would be already attached to the substratum. The Kolmogorov-Smirnov two-sample test was used to compare diaspore survival in different zones. For each pollution zone and time of observation, two sets of data were analysed (base of trunk and $130 \mathrm{~cm}$ ). Data from individual trees and localities within the same zone were combined.

Two representative bark samples (one from the base of the trunk and one from $130 \mathrm{~cm}$ ) were collected at each sampling time from each pollution zone and stored air-dry for subsequent SEM examination. To cover the eventuality of an insufficient number of diaspores or excessive variation of developmental stages within the same zone (as assessed under the dissecting microscope), an additional 1 or 2 squares were collected. The specimens were evacuated in a high-vacuum sputter coater MED 010 (Bal-Tec, Balzers, Principality of Liechtenstein) and coated with $30 \mathrm{~nm}$ of gold. Specimens were investigated in an Philips 515 SEM (Eindhoven, The Netherlands) at $12 \mathrm{kV}$ accelerating voltage immediately after sputter coating. A total of 70 bark specimens were SEM-examined. 
TABLE 1. Characteristics of sample sites (from Scheidegger 1998)

\begin{tabular}{|c|c|c|c|c|}
\hline \multirow[b]{2}{*}{ Parameter } & \multicolumn{4}{|c|}{$\begin{array}{l}\text { Zone of the load and distance }(\mathrm{km}) \\
\text { from the emission source }\end{array}$} \\
\hline & $\begin{array}{l}\text { Lichen desert } \\
\qquad(1-2)\end{array}$ & $\begin{array}{l}\text { Impact } \\
(4-5)\end{array}$ & $\begin{array}{l}\text { Buffer } \\
(7-8)\end{array}$ & $\begin{array}{c}\text { Background } \\
\quad(18-28)\end{array}$ \\
\hline \multicolumn{5}{|c|}{ Metal concentrations in soil $(\mathrm{ppm})^{\star}$} \\
\hline $\mathrm{Cu}$ & $3437-4140$ & $709-971$ & $585-606$ & $25-52$ \\
\hline $\mathrm{Zn}$ & $309-210$ & $289-466$ & $303-529$ & $38-73$ \\
\hline $\mathrm{Pb}$ & $410-803$ & $119-260$ & $208-248$ & $22-30$ \\
\hline $\mathrm{Cd}$ & $6 \cdot 4-9 \cdot 7$ & $6 \cdot 7-9 \cdot 2$ & $8 \cdot 0-9 \cdot 9$ & $0 \cdot 7-1 \cdot 0$ \\
\hline \multicolumn{5}{|c|}{ Pollutant concentrations in $H$. physodes thalli (ppm) $\ddagger$} \\
\hline $\mathrm{Cu}$ & $-\$$ & $-\$$ & $226-290$ & $116-144$ \\
\hline $\mathrm{Zn}$ & - & - & $359-444$ & $244-326$ \\
\hline $\mathrm{Pb}$ & - & - & $135-149$ & $86-100$ \\
\hline $\mathrm{Cd}$ & - & - & $4 \cdot 9-5 \cdot 4$ & $2 \cdot 8-5 \cdot 3$ \\
\hline$S$ & - & - & $1041-1153$ & $1145-1205$ \\
\hline $\begin{array}{l}\text { Number of lichen } \\
\text { species on birch }\end{array}$ & $0-1$ & $5-6$ & $9-10$ & 16 \\
\hline IAP & 0 & $1 \cdot 0-1 \cdot 8$ & $1 \cdot 9-3 \cdot 1$ & $9 \cdot 4-14 \cdot 8$ \\
\hline
\end{tabular}

${ }^{\star}$ Metal concentrations ( $5 \% \mathrm{HNO}_{3}$ extractable forms) were measured in upper soil layer by AAS-method.

‡Concentrations were measured by ICP-AES method after wet digestion in $\mathrm{HNO}_{3}+\mathrm{HF}$.

$\$ H$. physodes is absent or present in small amounts which do not allow a chemical analysis.

- Index of Atmospheric Purity (IAP) was calculated according to formulae IAP $=1 / 10 \Sigma_{i=1}^{n} \boldsymbol{Q}_{i} \boldsymbol{F}_{i}$, where $\boldsymbol{Q}_{i}$ is an ecological index of the $i$ th species (calculated as an average number of accompanying species), $\boldsymbol{F}_{i}$ is the frequency of the $i$ th species on the trunk (range $1-10$ ), $n$ is the number of species at the sample site.

\section{Results}

\section{Quantitative analyses of diaspore survival}

At the beginning of the experiment, the bark squares were densely covered with soredia. After 2 months several hundred soredia were found on each bark square. During the next 2 months, until the end of the growth period, more than $50 \%$ of the soredia which were present after 2 months survived on the majority of bark specimens (Table 2). A comparison of frequency distributions revealed significant $(P<0.001)$ differences between the survival of soredia in the lichen desert (both at the base of trunks and at $130 \mathrm{~cm}$ ) and in the impact (at the base of trunks) zones compared with survival under background conditions. These differences were due to samples with a frequency of diaspore survival $>75 \%$. Moreover, in the lichen desert more than $90 \%$ of the diaspores survived in $63 \cdot 16$ and $49 \cdot 12 \%$ of the specimens at the upper parts $(130 \mathrm{~cm})$ and the bases of trunks, respectively, while the corresponding frequencies for background conditions were 21.59 and $24.42 \%$.

During the subsequent winter a considerable loss of propagules occurred as shown by survival frequencies after 12 months of exposure. However, the portion of samples with a high survival rate $(>50 \%)$ was still notable (Table 2) and a complete loss of soredia was registered in only a few samples. In contrast to the first growth period, the diaspore survival in the different pollution zones after 12 months were broadly similar.

During the second growth period, between 12-16 months, a high loss of propagules occurred (Table 2). All survival frequency distributions shifted to the lowest class. The Kolmogorov-Smirnov test showed significant differences between survival in the lichen desert at $130 \mathrm{~cm}$ $(P<0.001)$ and the impact zone, both on 
TABLE 2. Frequency distributions of diaspore survival after 4, 12 and 16 months

\begin{tabular}{|c|c|c|c|c|c|c|c|c|}
\hline \multirow{2}{*}{$\begin{array}{l}\text { Duration of } \\
\text { exposure } \\
\text { (months) }\end{array}$} & \multirow{2}{*}{$\begin{array}{l}\text { Zone of the } \\
\text { load and position } \\
\text { on a trunk }\end{array}$} & \multicolumn{6}{|c|}{ Ranges of survival $(\%)$} & \multirow[b]{2}{*}{$P+$} \\
\hline & & 0 & $0 \cdot 1-5$ & $5 \cdot 1-25$ & $25 \cdot 1-50$ & $50 \cdot 1-75$ & $>75$ & \\
\hline \multirow[t]{12}{*}{4} & Lichen desert: & & & & & & & \\
\hline & $130 \mathrm{~cm}$ & $0 \cdot 0$ & $0 \cdot 0$ & $0 \cdot 0$ & $5 \cdot 3$ & $7 \cdot 0$ & $87 \cdot 7$ & $\star \star \star$ \\
\hline & base & $0 \cdot 0$ & $0 \cdot 0$ & $0 \cdot 0$ & $5 \cdot 3$ & $8 \cdot 8$ & $84 \cdot 2$ & $\star \star \star$ \\
\hline & Impact: & & & & & & & \\
\hline & $130 \mathrm{~cm}$ & $0 \cdot 0$ & $1 \cdot 1$ & $8 \cdot 00$ & $14 \cdot 8$ & $28 \cdot 4$ & $47 \cdot 7$ & - \\
\hline & base & $0 \cdot 0$ & $0 \cdot 0$ & $7 \cdot 9$ & $7 \cdot 9$ & $19 \cdot 1$ & $64 \cdot 0$ & $\star \star \star$ \\
\hline & Buffer: & & & & & & & \\
\hline & $130 \mathrm{~cm}$ & $0 \cdot 0$ & $1 \cdot 2$ & $9 \cdot 3$ & $20 \cdot 9$ & $25 \cdot 6$ & $43 \cdot 0$ & - \\
\hline & base & $0 \cdot 0$ & $0 \cdot 0$ & $10 \cdot 5$ & $10 \cdot 5$ & $25 \cdot 6$ & $53 \cdot 5$ & $-\cdots$ \\
\hline & Background: & & & & & & & \\
\hline & $130 \mathrm{~cm}$ & $0 \cdot 0$ & $0 \cdot 0$ & $18 \cdot 2$ & $10 \cdot 2$ & $14 \cdot 8$ & $56 \cdot 8$ & \\
\hline & base & 0.0 & $0 \cdot 0$ & $15 \cdot 1$ & $17 \cdot 4$ & $20 \cdot 9$ & 46.5 & \\
\hline \multirow[t]{12}{*}{12} & Lichen desert: & & & & & & & \\
\hline & $130 \mathrm{~cm}$ & $0 \cdot 0$ & $9 \cdot 1$ & $43 \cdot 6$ & $29 \cdot 1$ & $7 \cdot 3$ & $10 \cdot 9$ & - \\
\hline & base & $0 \cdot 0$ & $9 \cdot 1$ & $32 \cdot 7$ & $38 \cdot 2$ & $18 \cdot 2$ & $1 \cdot 8$ & - \\
\hline & Impact: & & & & & & & \\
\hline & $130 \mathrm{~cm}$ & $2 \cdot 3$ & $13 \cdot 8$ & $36 \cdot 8$ & $36 \cdot 8$ & $9 \cdot 2$ & $1 \cdot 2$ & - \\
\hline & base & $5 \cdot 7$ & $5 \cdot 7$ & $21 \cdot 6$ & $37 \cdot 5$ & $17 \cdot 1$ & $12 \cdot 5$ & — \\
\hline & Buffer: & & & & & & & \\
\hline & $130 \mathrm{~cm}$ & $1 \cdot 2$ & $8 \cdot 2$ & $40 \cdot 0$ & $28 \cdot 2$ & $12 \cdot 9$ & $9 \cdot 4$ & 一 \\
\hline & base & $2 \cdot 3$ & $5 \cdot 8$ & $31 \cdot 0$ & $28 \cdot 7$ & $18 \cdot 4$ & $13 \cdot 8$ & - \\
\hline & Background: & & & & & & & \\
\hline & $130 \mathrm{~cm}$ & $1 \cdot 2$ & $4 \cdot 9$ & $39 \cdot 0$ & $23 \cdot 2$ & $19 \cdot 5$ & $12 \cdot 2$ & \\
\hline & base & $4 \cdot 8$ & $9 \cdot 5$ & $36 \cdot 9$ & $32 \cdot 1$ & $11 \cdot 9$ & $4 \cdot 8$ & \\
\hline \multirow[t]{12}{*}{16} & Lichen desert: & & & & & & & \\
\hline & $130 \mathrm{~cm}$ & $80 \cdot 8$ & $17 \cdot 3$ & 0.0 & 1.9 & $0 \cdot 0$ & 0.0 & $\star \star \star$ \\
\hline & base & $44 \cdot 6$ & $25 \cdot 9$ & $29 \cdot 6$ & 1.9 & $0 \cdot 0$ & $0 \cdot 0$ & - \\
\hline & Impact: & & & & & & & \\
\hline & $130 \mathrm{~cm}$ & $29 \cdot 6$ & $42 \cdot 1$ & $23 \cdot 9$ & $4 \cdot 6$ & $1 \cdot 1$ & $0 \cdot 0$ & $\star \star$ \\
\hline & base & $36 \cdot 1$ & $37 \cdot 2$ & $25 \cdot 6$ & $1 \cdot 2$ & $0 \cdot 0$ & 0.0 & $\star$ \\
\hline & Buffer: & & & & & & & \\
\hline & $130 \mathrm{~cm}$ & $20 \cdot 6$ & $55 \cdot 1$ & $20 \cdot 5$ & $2 \cdot 6$ & $1 \cdot 3$ & $0 \cdot 0$ & $\ldots$ \\
\hline & base & $17 \cdot 3$ & $53 \cdot 1$ & $23 \cdot 5$ & $4 \cdot 9$ & $1 \cdot 2$ & $0 \cdot 0$ & - \\
\hline & Background: & & & & & & & \\
\hline & $130 \mathrm{~cm}$ & $19 \cdot 3$ & $44 \cdot 6$ & $27 \cdot 7$ & $6 \cdot 0$ & $0 \cdot 0$ & $2 \cdot 4$ & \\
\hline & base & $17 \cdot 8$ & $35 \cdot 4$ & $34 \cdot 2$ & $10 \cdot 1$ & $2 \cdot 5$ & 0.0 & \\
\hline
\end{tabular}

$f-=P>0.05,^{\star}=P<0.05,{ }^{\star} \star=P<0.01,{ }^{\star}{ }^{\star \star}=P<0.001$ (Kolmogorov-Sminov two-sample test, comparison with background zone).

base of trunk $(P<0.05)$ and at $130 \mathrm{~cm}$ $(P<0 \cdot 01)$ as compared to background conditions. The main reason for these differences was the higher frequency of bark specimens with no surviving soredia in the most polluted zones. This is especially apparent on the upper parts of trunks in the lichen desert where a complete loss of propagules occurred in $80.77 \%$ of the bark specimens. At the same time, a high percentage of propagules survived at the base of trunks in this locality [differences between positions at the trunk are highly significant $(P<0.001)]$.

\section{SEM investigations under the background conditions}

During the first 29 months of the early development of $H$. physodes soredia, five developmental stages could be distinguished. 
1. Soredial stage. Soredia are of globular shape (Fig. 1A) with hyphae covered by needle-like crystals of lichen substances. Small amounts of a gelatinous substance were produced around single hyphae. At this stage, development was very rapid so that after only 2 months of exposure very few soredia were observed. It is likely that some soredia which were not attached to the substratum were lost during specimen storage and preparation. Furthermore, excessive electrical charging during SEM observation hampered an accurate observation of this stage.

2. Granular stage. After two months of exposure, the majority of diaspores reached this stage. Soredia developed outgrowing hyphae with a smooth cell wall with predominantly anticlinal growth. On the surface of soredia, patches of gelatinous substance expand between hyphae (Fig. 1B) and, after 4 months, form a thin and broken layer on the upper part of the soredia (Fig. 1C \&D). The film of jelly was usually lacking in the lower part of the soredia where fungal hyphae encrusted with crystals formed a disjunct layer. No further development occurred until the following growing season i.e. May (12 months).

3. Thallus primordium. Pseudomeristematic growth (budding of cortical hyphae) was found to start laterally on soredial clumps where the gelatinous layer was incompletely developed. We never observed vertical growth of soredial clumps. Like the soredial stage, the thallus primordium stage seems to be very short-lived and hence was rarely observed.

4. Lobulate stage. In September, after the second growth period ( 16 months), some of the soredia developed into ascendant lobes about $0.1 \mathrm{~mm}$ length (Fig. 1E \& F). From one granular stage, a single lobe usually developed. Observations with the dissecting microscope revealed that these lobes were dorsiventral with a greenish upper and a dark lower side. The upper side was formed by isodiametric hyphal cells contiguously covered with a thin cartilaginous matrix layer-the epicortex. At the margin of the lobes, the epicortex was incompletely developed with gaps of $1-10 \mu \mathrm{m}$. In these gaps, the isodiametric cortical cells were separated by minute intercellular air spaces. After 25 months, spathulate lobes developed and grew adpressed to the bark substratum. After 29 months, overviews of cohorts showed undirected growth of the lobes and no geotropic growth preference was visible until the end of the experiment (Fig. 2F).

5. Branched lobes. After 29 months, the majority of lobes were still simple but some showed the first signs of branching.

\section{Development from groups of soredia}

Adjacent single soredia may coalesce during development (Fig. 2A) through hyphal growth from one soredium to another. Although such contacts over a few $\mu \mathrm{m}$ were regularly observed, we found no direct evidence for contacts between soredia over a longer distance. However, we often observed development from clusters consisting of three or more soredial subunits in the background (Fig. 2B), and also in polluted zones (Fig. 2C). In these cases, the first stages of lobe formation consisted of several even-aged stages derived from one cluster (Fig. 2D-F).

\section{SEM investigations in polluted areas}

The early (granular) stages described above for the first 12 months in the background zone were also found in the various polluted zones including the lichen desert (Table 3). Similar outgrowing hyphae were observed in all pollution zones after two months. After two to four months, gelatinous layers were formed on the upper parts of the soredial clumps; however, unlike the development in the background zone this layer was often considerably thicker and rougher (Fig. 3A \& B).

Buffer zone. After 16 months at the bases of the trunk, the majority of the granules formed a smooth gelatinous layer (Fig. 3C). A few developed into lobes with a distinct growth zone. The cartilaginous layer of the epicortex covered the lobes only incompletely, and where no epicortex was developed, the globular cortical cells were visible 


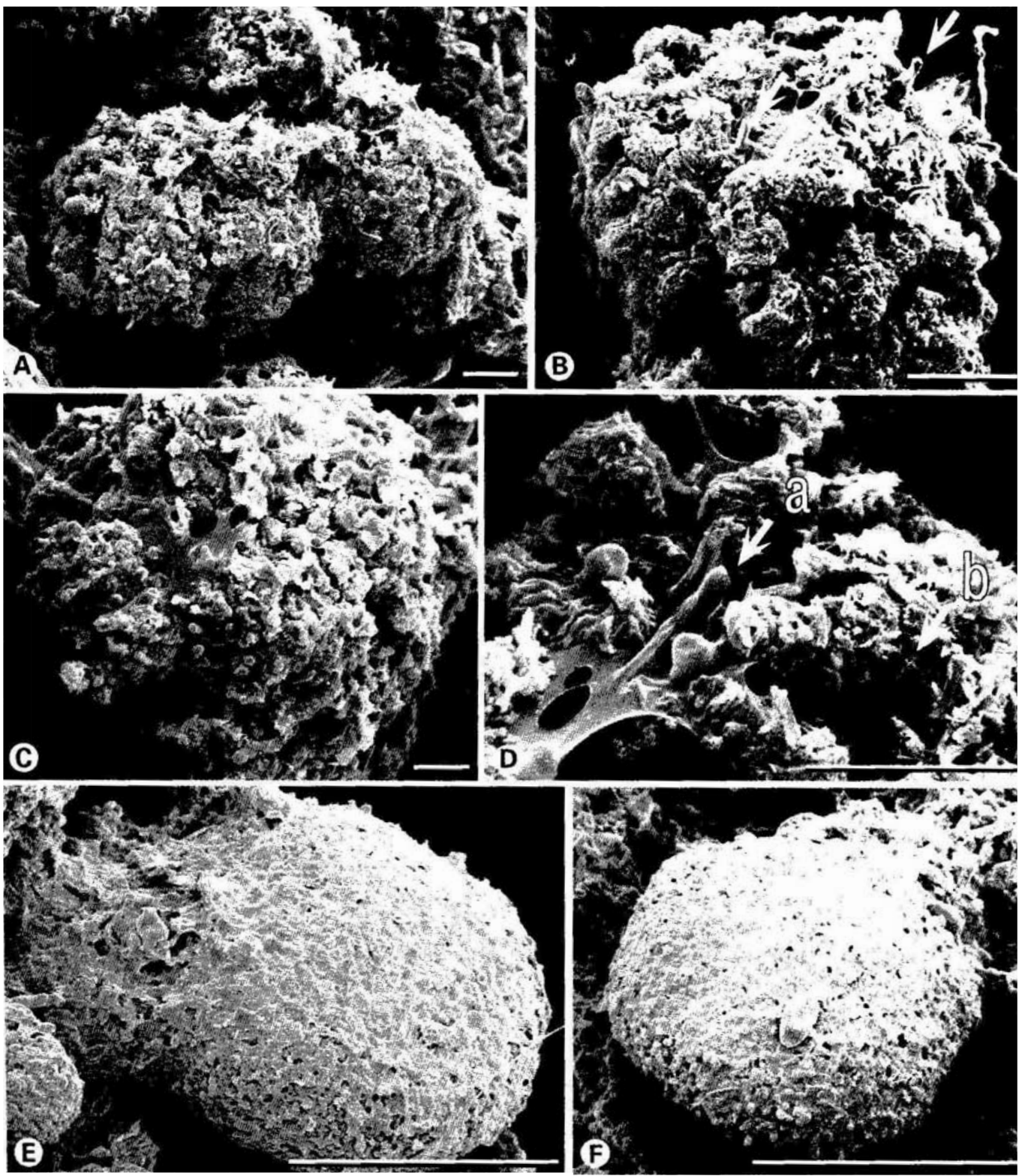

Fig. 1. Early development of soredia under background conditions. A soredial stage after furo monthe exporetre: B, granular stage after two months exposure with smooth anticlinal outgrowing hrphac (arrows), small patches a gelatinous substance are present; $C$ \& D, granular stage after 4 months exposure with expanded patches gelatinous substance (note smooth cell wall of the newly formed anticlinal fungal hyphac a) and the needte-like crystals (b) covering the older, periclinal hyphae); E \& F, lobulate stages after 16 months exposure (note gelatinous substance forming the epicortex on the upper side of the lobules which is incompletely developed at the margin of lobules). Scales: A-D $=10 \mu \mathrm{m} ; \mathrm{E} \& \mathrm{~F}=0.1 \mathrm{~mm}$. 

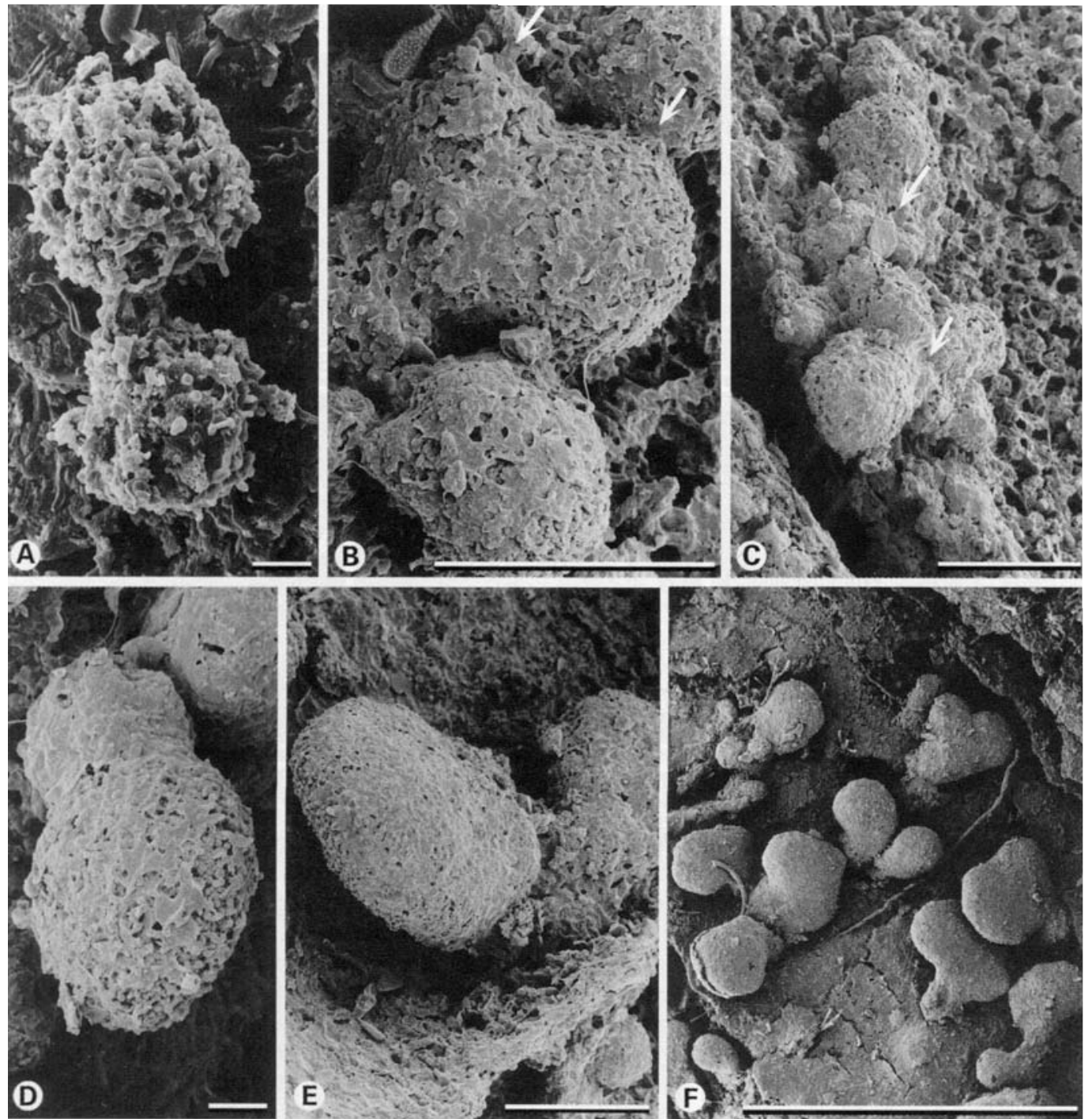

FIG. 2. Early development of soredial groups (A: buffer zone; B, D-F: background zone; C: impact zone). A, granular stage after 4 months exposure with outgrowing hyphae establishing fungal contact zones between the diaspores; B \& C, hyphal contacts between a group of several granular stages embedded in gelatinous substance after 16 months exposure (arrows); D \& E, early stage of lobulate stages, which develop from a group of granular stages after 16 months exposure; F, an even-aged group of lobulate stages after 29 months exposure with lobes developing in various directions despite the vertical orientation of the substratum. Scales: $A=10 \mu \mathrm{m}, \mathrm{B}-\mathrm{E}=0.1 \mathrm{~mm}$, $\mathrm{F}=1 \mathrm{~mm}$

(Fig. 3D). On the trunk $130 \mathrm{~cm}$ above the base, only granular structures with a rough jelly developed. After 25 months, a few imperfect lobulate stages were present but by far most stages were granular with a rough gelatinous layer (Table 3 ).
Impact zone. After 16 months, the majority of the soredia were at the granular stage. A few did not produce any layer of gelatinous substance but developed long outgrowing hyphae. Lobes with an uneven surface where the epicortex was regularly broken 
TABLE 3. Frequency $(\dagger)$ of developmental stages of $\mathbf{H}$. physodes soredia in the different pollution zones

\begin{tabular}{|c|c|c|c|c|c|c|c|}
\hline \multirow{2}{*}{$\begin{array}{l}\text { Zone } \\
\text { of the load }\end{array}$} & \multirow{2}{*}{$\begin{array}{l}\text { Developmental } \\
\text { stage }\end{array}$} & \multicolumn{6}{|c|}{ Duration of exposure (months) } \\
\hline & & 2 & 4 & 12 & 16 & 25 & 29 \\
\hline \multirow[t]{5}{*}{ Lichen desert } & Soredial & * & $\star$ & $\star$ & $\star$ & $\star \star$ & - \\
\hline & Granular & $\star \star \star$ & $\star \star \star$ & $\star \star \star$ & $\star \star \star$ & $\star \star \star$ & - \\
\hline & Thallus primordia & - & - & - & * & - & - \\
\hline & Simple lobes & - & - & - & $\star$ & - & - \\
\hline & Branched lobes & - & - & - & - & - & - \\
\hline \multirow[t]{5}{*}{ Impact } & Soredial & - & - & - & - & - & - \\
\hline & Granular & $\star \star \star$ & $\star \star \star$ & $\star \star \star$ & $\star \star \star$ & $\star \star \star$ & $\star \star$ \\
\hline & Thallus primordia & - & - & - & * & - & - \\
\hline & Simple lobes & - & - & - & $\star$ & $\star$ & $\star \star$ \\
\hline & Branched lobes & - & - & - & - & - & - \\
\hline \multirow[t]{5}{*}{ Buffer } & Soredial & - & - & - & - & - & - \\
\hline & Granular & $\star \star \star$ & $\star \star \star$ & $\star \star \star$ & $\star \star \star$ & $\star \star \star$ & $\star \star$ \\
\hline & Thallus primordia & - & - & - & * & - & -- \\
\hline & Simple lobes & - & - & - & $\star$ & $\star$ & $\star \star$ \\
\hline & Branched lobes & - & - & - & - & - & - \\
\hline \multirow[t]{5}{*}{ Background } & Soredial & $\star$ & - & - & - & - & - \\
\hline & Granular & $\star \star \star$ & $\star \star \star$ & $\star \star \star$ & $\star$ & $\star$ & $\star$ \\
\hline & Thallus primordia & - & - & 一 & - & - & 一 \\
\hline & Simple lobes & - & - & - & $\star \star \star$ & $\star \star \star$ & $\star \star \star$ \\
\hline & Branched lobes & - & - & - & - & - & $\star$ \\
\hline
\end{tabular}

$\ddagger-=$ absent, ${ }^{\star}=$ unique or very rare, ${ }^{\star \star}=$ frequent, ${ }^{\star \star \star}=$ dominant.

developed particularly from extended soredial clusters (Fig. 3E \& F). In these gaps in the epicortex, bubble-like cortical cells were visible. Other granular stages were completely covered with a thick layer of rough cartilaginous material that expanded to the base of soredial clumps. After 25 months, a few lobulate stages developed but granular stages with a rough layer of gelatinous substance were dominant (Table 3).
Lichen desert. Some soredia developed a gelatinous layer and conspicuous outgrowing hyphae after only 2 months (Fig. $3 \mathrm{H} \&$ I). After 16 months, a few stages developed further into lobes about $0.1 \mathrm{~mm}$ length. These stages were confined to cracks on the bark substratum. Even their marginal zones were partially covered with an epicortex (Fig. 3G). However, after 25 months no lobes occurred and soredial (Fig. 3J) as well

FIG. 3. Early development of soredia under polluted conditions (A-D: buffer zone, E \& F: impact zone, G-K: lichen desert zone). A, a granular stage with a thick layer of rough gelatinous substance (arrows) after 4 months exposure; B, a granular stage with atypically long outgrowing hyphae and a thick layer of rough gelatinous substance after 4 months exposure; $\mathrm{C}$, a granular stage covered with a smooth layer of gelatinous substance after 16 months exposure; D, a lobulate stage incompletely covered with a smooth layer of gelatinous substance after 16 months exposure (note globular cortical cells in gaps); E, lobulate stages developed from soredial clusters after 16 month exposure; F, lobulate stages with an uneven surface and irregular cracks in the gelatinous substance after 16 months exposure; $G$, a layer of gelatinous substance covers even parts of the marginal zone (arrow) of this lobulate stage after 16 months exposure; $\mathrm{H}$, granular stages covered with a layer of gelatinous substance after 2 months exposure; I, granular stages with a layer of gelatinous substance and anticlinal outgrowing hyphae after 2 months exposure; J, soredial stages after 25 months exposure; $\mathrm{K}$, granular stages with an incomplete layer of gelatinous substance after 25 months exposure. Scales: A, B \& I=10 $\mu \mathrm{m}, \mathrm{C}-\mathrm{H}, \mathrm{J} \& \mathrm{~K}=0 \cdot 1 \mathrm{~mm}$. 

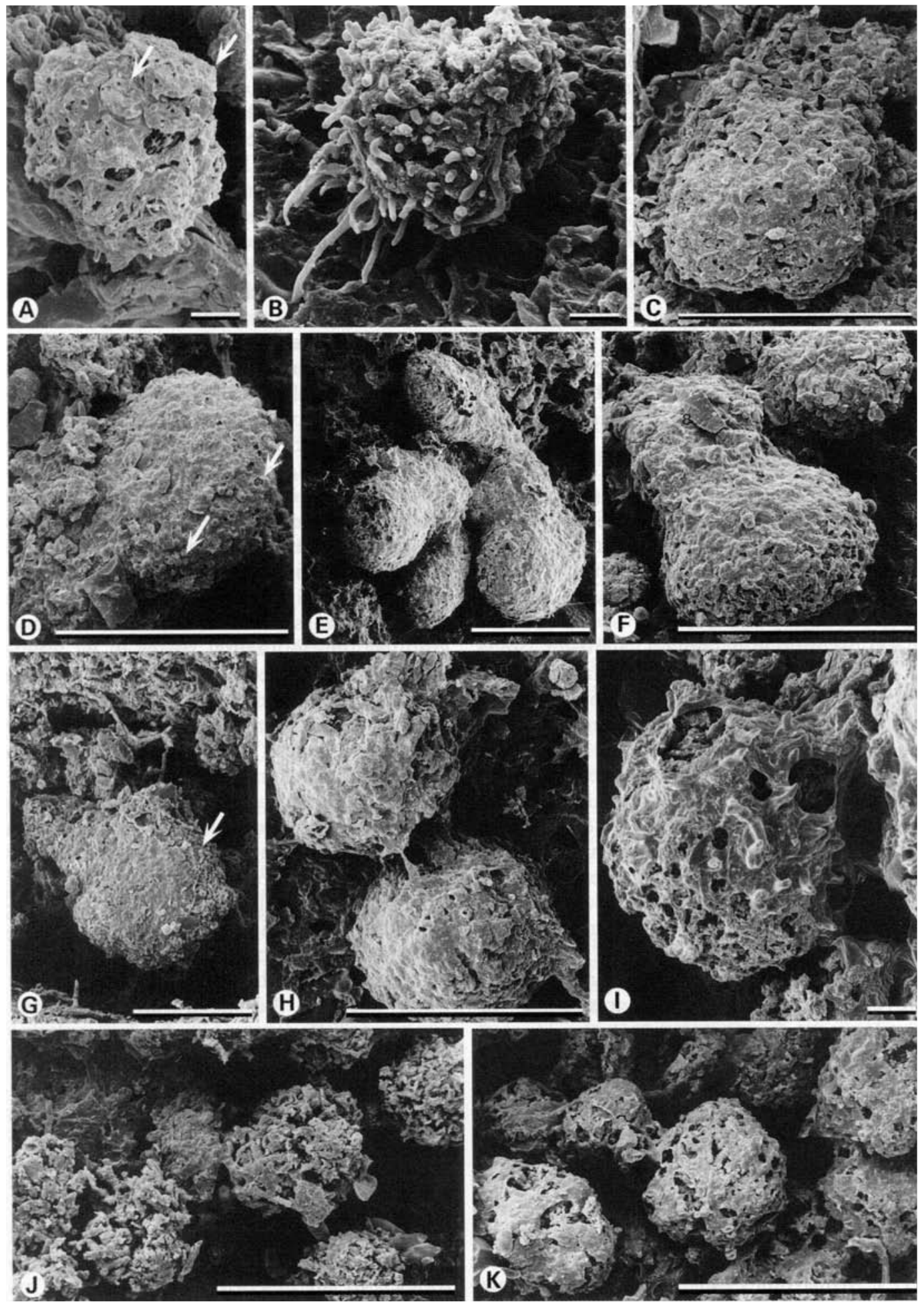
as granular stages which were partly covered by a layer of gelatinous substance, were equally numerous (Fig. 3K). After 29 months no propagules survived on the transplanted bark specimens (Table 3).

\section{Discussion}

The early development of $H$. physodes diaspores under the continental climate of the Middle Urals differs considerably from that in a more oceanic climate in Central Europe. Soredia were never found with such long outgrowing hyphae as are typical of the 'arachnoidal stage' described by Schuster (1985). Therefore, the 'spider-net' stage which is the consequence of the coalescence of several propagules at the 'arachnoidal stage' was never seen, although contacts between closely situated soredia occurred. Differences were also evident in the developmental rates. Lobe formation was found after 11-16 months in an oceanic climate (Ott 1987a,b) and between 17-25 months in a sub-continental climate (Schuster 1985) of Central Europe. In the latter case, semirosette-shaped thalli of $2 \mathrm{~mm}$ size occurred after 25 months. In the present study in the Middle Urals, the first lobes were found after 16 months but even after 29 months the majority were still unbranched and less than $0.5 \mathrm{~mm}$ long (Table 3 ). These slow developmental rates can probably be explained by a shorter growth period in our study area where $H$. physodes developed only during the five summer months (MaySeptember). Ott $(1987 a)$, on the other hand, reported a fast development from November to May and inhibition of development during summer.

The percentage of survival on the experimental bark specimens was highly variable within the same site (Table 2) presumably due to differences in surface microtopography and hence inoculation capacity of individual bark squares. Importance of the surface features for the attachment and early development of diaspores has already been postulated in several studies (Brodo 1973; Armstrong 1990). During the first few months, soredia survived in the most polluted zone better than under background conditions. After 12 months, survival was equally high in all the pollution zones and only after 16 months of the experiment did the negative influence of toxic emissions became evident. The first symptoms of damage included a high mortality of the propagules in the lichen desert and a better survival of propagules on bases of trunks. Here they are developing under more favourable water relations and are sheltered from pollution by grass stands and snow cover. At the same time, the first differences in developmental rates were registered (Table 3). While simple lobes were predominant under background conditions and some imperfect lobes were present in the polluted zones, granular and even soredial (in the lichen desert) stages were still numerous in all polluted zones. After 29 months branched lobes were found under background conditions but no further development occurred in the polluted regions.

The equal survival of the soredial and granular developmental stages in all pollution zones and their survival for 25 months even in the lichen desert suggest these stages are very tolerant of toxic influences. These pre-thallus stages (Honegger 1996) have no developed cortex and are not stratified. The SEM micrographs in the present study showed large quantities of crystalline lichen products encrusting the hyphal walls of the soredial stage and also of the granular stage where the extracellular matrix was incomplete. Hydrophobic hyphal surfaces of the pre-thallus stages partially avoid the contact with pollutant-rich water run-off because water films on the substratum are usually interrupted, for example, by hydrophobic lichen compounds which may extend on to the substratum (Scheidegger, unpublished). The rare occurrence of further developmental stages in polluted zones means either a cessation of development after the granular stage and/or increased mortality of the subsequent stages. We suggest that the sensitivity of the developmental stages is increased as soon as pseudomeristematic growth zones and an epicortex are formed. This 
explanation is supported by the fact that the upper cortex is hydrophilic and is structurally adapted to a rapid apoplastic uptake of a substantial amount of water (Scheidegger et al., 1997). As a result, these stages are more directly exposed to pollutants transported in the water run-off.

Schuster et al. (1985) described an ungelatinized and porous cortex as a significant morphological disturbance in young, stratified thalli growing in a polluted environment. However, our data demonstrate the formation of a thicker and rougher gelatinous layer on granular and partly on lobulate stages in the polluted localities studied here. It is not clear if these differences are due to the different types of pollution or to differences in climatic conditions.

The existence of natural $H$. physodes populations, though of sharply reduced density, in the impact and buffer zones is the best evidence of the ability of propagules to successfully develop into adult thalli. However, our data indicate a significant increase in the duration of the early developmental stages in polluted areas. Therefore, this study confirms a recent suggestion (Mikhailova \& Vorobeichik 1999) that environmental pollution may decrease the developmental rate of $H$. physodes.

We thank Mrs O. V. Matiyash for her help in field and laboratory work and in data analyses, Dr B. Frey for the support in the SEM investigations, Dr D. Pezzotta for providing for the chemical analyses of lichen samples and $\operatorname{Dr} O$. W. Purvis for reading the manuscript and correcting the language. We also acknowledge INTAS for the financial support (project 93-1645).

\section{REFERENCES}

Armstrong, R. A. (1990) Dispersal, establishment and survival of soredia and fragments of the lichen, Hypogymnia physodes (L.) Nyl. New Phytologist 114: $239-245$.

Brodo, I. M. (1973) Substrate ecology. In The Lichens (V. Ahmadjian \& M. E. Hale, eds): 401-441. New York: Academic Press.

De Sloover, J. \& LeBlanc, F. (1970) Pollutions atmosphériques et fertilité chez les mousses et les lichens epiphytiques. Bulletin de la Académie et de la Société Lorraines des Sciences 9: 82-90.

Garty, J. (2000) Trace metals, other chemical elements and lichen physiology: research in the nineties.
In Trace Elements-Their Distribution and Effects in the Environment (B. Markert \& K. Friese, eds): 277-322. Amsterdam: Elsevier.

Gries, C. (1996) Lichens as indicators of air pollution. In Lichen Biology (T. H. Nash III, ed.): 240-254. Cambridge: Cambridge University Press.

Holopainen, T. (1984) Types and distribution of ultrastructural symptoms in epiphytic lichens in several urban and industrial environments in Finland. Annales Botanici Fennici 21: 213-229.

Honegger, R. (1996) Morphogenesis. In Lichen Biology (T. H. Nash III, ed.): 65-87. Cambridge: Cambridge University Press.

Kolesnikov, B. P., Zubareva, R. S. \& Smolonogov, E. P. (1973) Lesorastitel'nye usloviya i tipy lesov Sverdlovskoi oblasti. Sverdlovsk: UNC AN SSR. [In Russian.]

Marti, J. (1985) Die Toxizität von Zink, Schwefel- und Stickstoffverbindungen auf Flechten Symbionten. Bibliotheca Lichenologica 21: 1-129.

Mikhailova, I. N. (1994) Epiphytic lichen communities. In Ecological Standardization of Terrestrial Ecosystems Technogenic Pollution (local scale) (E. L. Vorobeichik, O. F. Sadykov \& M. G. Farafontov, eds): 210-216. Ekaterinburg: Nauka. [In Russian.]

Mikhailova, I. N. (1998) Populations of Hypogymnia physodes (L.) Nyl. under the stress conditions. In Lobarion Lichens as Indicators of the Primeval Forests of the Eastern Carpathians (S. Kondratyuk \& B. Coppins, eds): 174-175. Kiev: Phytosociocentre.

Mikhailova, I. N. \& Vorobeichik, E. L. (1999) Dimensional and age structure of populations of epiphytic lichen Hypogymnia physodes (L.) Nyl. under conditions of atmospheric pollution. Russian fournal of Ecology 30: 130-137.

Nash III, T. H. \& Gries, C. (1991) Lichens as indicators of air pollution. In Handbook of Environmental Chemistry Vol. 4. Part C (O. Hutzinger, ed.): 1-29. Berlin: Springer-Verlag.

Ott, S. (1987a) Differences in developmental rates of lichens. Annales Botanici Fennici 24: 385-393.

Ott, S. (1987b) The juvenile development of lichen thalli from vegetative diaspores. Symbiosis 3: 57-74.

Prokaev, V. I. (1976) Phiziko-geograficheskoe raionirovanie Sverdlovskoi oblasti. Part 1. Sverdlovsk: Sverdlovskii gosudarstvennyi pedagogicheskii institut. [In Russian.]

Richardson, D. H. S. (1992) Pollution Monitoring with Lichens. Slough: Richmond Publishing Company.

Scheidegger, C. (1998) Lichen bioindication and morphophysiological characterisation of tree stands for an ecological monitoring of forests in polluted areas in the Middle Urals (Russia, Sverdlovsk Region). INTAS final report 93-12645. Brussels, INTAS.

Scheidegger, C., Frey, B. \& Schroeter, B. (1997) Cellular water uptake, translocation and PSII activation during rehydration of desiccated Lobaria pulmonaria (lichenised ascomycete). Bibliotheca Lichenologica 67: 105-117. 
Scheidegger, C. \& Mikhailova, I. (2000) Umweltforschung-Flechten als Bioindikatoren für die Luftverschmutzung im Ural: Eindrücke von einem gemeinsamen Forschungsprojekt. In Naturwerte in Ost und West. Forschen für eine nachhaltige Entwicklung vom Alpenbogen bis zum Ural (R. Landolt, ed.). Birmensdorf: Eidgenössische Forschungsandstalt WSL.

Schuster, G. (1985) Die Jugendentwicklung von Flechten-ein Indikator für Klimabedingungen und Umweltbelastung. Bibliotheca Lichenologica 20: 1-206.

Schuster, G., Ott, S. \& Jahns, H. M. (1985) Artificial cultures of lichens in the natural environment. Lichenologist 17: 247-253.
Sigal, L. L. \& Nash III, T. H. (1983) Lichen communities on conifers in southern California mountains: an ecological survey relative to oxidant air pollution. Ecology 64: 1345-1354.

Skye, E. (1968) Lichens and air pollution. Acta Phytogeographica Suecica 52: 1-138.

Vorobeichik, E. L. \& Khantemirova, E. V. (1994) Reaction of forest phytocenoses to technogenic pollution: dose-effect dependencies. Russian foumal of Ecology 25: 171-180.

Vorobeichik, E. L., Sadykov, O. F. \& Farafontov, M. G. (1984) Ecological Standardization of Terrestrial Ecosystems Technogenic Pollution (local scale). Ekaterinburg: Nauka. [In Russian.] 